\title{
DEVELOPING PREZI NEXT AS TEACHING MEDIA OF RECOUNT TEXT FOR EIGHTH GRADE OF JUNIOR HIGH SCHOOL
}

\author{
*Ari Tata Pratama \\ **Nora Ronita Dewi, S.Pd., S.S., M.Hum.
}

\begin{abstract}
Ari Tata Pratama. 2143321004. Developing Prezi Next As Teaching Media Of Recount Text For Eighth Grade Of Junior High School. A Thesis. Faculty of Languages and Arts. State University of Medan. 2021.

The aim of this stuy was to develop writing speaking through media for eightth grade of Junior High School Student in SMP Swasta Panca Abdi Binjai. By using Research \& Development design with six stages, they were Gathering Information and Data, Analyzing Data, Material Design, Validating by Experts, Revising, and Final Product. With 30 individuals responses as the data subjects through Interviews and Questionnaires. From the material, the first validator scored 75,8\% of excellent, and the score from the second validator was $82,8 \%$, and it was categorized as relevant. And from the media, $52 \%$ from the first validator, and $50 \%$ of the highest score from the second. In means that the media were valid and appropriate to use as learning media for students. The results of the product was Prezi Next as the presentation and learning online media for those individuals. Later on, the media was test using Recount Text as the measurement of the media to these subjects. This also leads to attractive media which introduced to help them motivated and keep interested. Thus, the media were valid and appropriate to use as learning media for students.
\end{abstract}

Keywords: Prezi Next, Recount Text, Research and Development.

\footnotetext{
*Graduate Status

**Lecturer Status
} 


\section{INTRODUCTION}

\section{Background of the Study}

Writing is needed to communicate with people. Because through writing they can convey the meaning of the information, ideas, opinions and feelings through the symbol of written language. People not only use spoken language but also written language. Writing is needed in daily life because our activity cannot be separated from the writing for instance chatting, taking notes, sending letters, writing a paragraph, etc.

Writing is one of four language skills which have to be mastered by the students, besides listening, speaking, and reading. Writing is the most difficult skills among of the other four skills. As stated by Feez (2002), among the other four skills, writing was considered as one of the most difficult language skills since it was a productive language skill. Writing is productive skill in English subject, because it produces a thinking process of idea, experience and feeling in written form.

According to the syllabus of Curriculum 2013, students are demanded to master some genres in writing, which are (1) Descriptive text, (2) Recount text, (3) Narrative text, (4) Report text, (5) Procedure text. One of the genres that students learned in Junior High School is Recount Text. Dirgayesa (2016) stated that "Recount text is a text that retells events or experiences in the past". It means that recount text is a text composed in order to give information about the past activities. 
The basic competency of recount text learning, based on the syllabus of English Lesson for Junior High School/Madrasah Tsanawiyah by Ministry of Education and Culture (2017) are:

\section{Recount Text}

Capturing contextual meaning related to social functions, generic structure, and language features of oral and written recount text, very short and simple according to the context. Arrange oral and written recount text, very short and simple related to personal experiences in the past (personal recount) by paying attention to social functions, generic structures, and language features of recount text correctly according to the context.

Nowadays, the teachers not only delivery the material by using blackboard in the class but the teacher must be creative to use the development of technology as media in teaching learning process. Arsyad (2011), one of the most influential development in the world of education is the development of technology. The effect of these developments is evident in efforts to reform the education and learning system. One integral part of the renewal efforts is teaching media. The use of teaching media as a result of the development of educational technology based on multimedia-based teaching media is expected to support the learning process. A teacher is expected to master the teaching media as a means or tool in learning activities.

Based on pre-observation and some discussions with the teacher in SMP Swasta Panca Abdi Bangsa Binjai, it is known that teachers have make use of 
development technologies such as computers and LCD projectors in teaching and learning process. However, in delivering the subject matter to the students, they still use mainstream presentation media such as Power Point. In general PowerPoint has purpose to help teacher in explaining recount text in teaching learning process. But in the application of PowerPoint in teaching recount text, the author found that students were less interested in the learning process because the PowerPoint display used by the teacher is not attractive. This causes the students feel bored when receiving lesson. In this case, researcher wants to make the writing learning process into an innovative and fun learning to get a learning process that is able to increase student enthusiasm, interest and motivation in learning Recount text.

There are many presentation media that can be used as teaching media today. By using innovative teaching media will create more interactive learning activities. One of the interesting teaching media is Prezi Next. Prezi is a presentation software that is also designed to display visual, audio and animation media. According to Wardani (2015), Prezi is a software that can help to make an attractive and creative presentation slides online. Prezi provides more free space to express creations and ideas in making presentation slides. One of the advantages of Prezi is using the Zooming User Interface (ZUI), which allows Prezi users to zoom in and out the display presentation media. Wisnu (2011) By using ZUI (Zooming User Interface) technology, users can zoom in and zoom out the frame in a presentation. Prezi can zoom in or zoom out of a slide quickly with a beautiful display. Prezi Next is a completely new presentation platform for 
Prezi. It is similar to the classic Prezi, however there are major differences in the way the software works, as Prezi Next now runs on HTML5, the classic version works on Adobe Flash software, which is regarded as unsafe with lots of performance issues.

Based on this background the writer wanted to do a research to develop Prezi Next as a writing learning media for eighth grade of Junior high school. The developed media hopefully could contribute to the teaching and learning process of writing Recount Text.

\section{REVIEW OF LITERATURE}

\section{Teaching Media}

Teaching media is one of the important aspects in efforts to achieve learning goals and serves to foster motivation to learn. As stated by Widayanto (2015) that teaching media is a media that bring messages or information that contain the aim or goal of teaching.

There are many kinds of media which can be used by the teachers in teaching learning process, so the teacher should be selective when choosing kinds of media.

\section{a. Kinds of Teaching Media}

The grouping of various types of media has been suggested by several experts, one of them is Rusman (2017) who classifies teaching media based on their nature, scope and techniques of use. By its character, the media can be 
divided into auditive media, visual media, audio visual media. Furthermore Arsyad (2011) classified the respective media into five groups, namely:

- Human-based media (teacher, instructor, tutor, role-playing, group activities, field-trip)

- $\quad$ Print-based media (guidebooks, workbooks, work aids).

- Visual based media (books, work aids, charts, graphs, maps, pictures, slides)

- $\quad$ Audio-visual media (video, film, program slide-type, television)

- Computer-based media (computer-assisted teaching, interactive video, hypertext)

From the statement of the expert above, it can be concluded that teaching media can be divided into several groups and each of them can be used according to the function of the media itself.

\section{b. Kinds of Teaching Media}

The media has a function as a carrier of information from the source (teacher) to the recipient (student). While the method is a procedure to help students in receiving and processing information in order to achieve learning objectives, defines by Daryanto (2010). From Arsyad (2011) statement, there are four functions of media, those functions are:

- Media can clarify the presentation of the message and information so that accelerate and improve the learning process and result.

- Media can improve and guide student attentions so that it can create learning motivation for them, create more direct interaction among student 
and their environment, and make them learn by themselves with appropriate ability and interest.

- Media can overcome the limitation of sense, space, and time.

- Media can give the same experience to student about the incident in their environment, and enable the occurrence of direct interaction with teachers, societies and their environment.

\section{c. The Benefits of Teaching Media}

Teaching media have use in teaching and learning process or activities. If teaching media is not used properly, then learning activities becomes less attractive and boredom arises in the students themselves. There are some benefits that can be obtain by the teacher according to Daryanto (2011), those are:

- Clarify the message so that it is not too verbalistic

- Overcoming the limitations of space, time and energy.

- Lead to enthusiasm for learning, a more direct interaction between student and learning resources.

- Enable students to learn, independently based on their talent and visual abilities.

- Giving the same stimulation, equalizing experience and giving rise to the same perception.

\section{d. Prezi Next}

Prezi Next is a presentation software that is also designed to display visual, audio and animation media. According to Wardani (2015), Prezi is a software that can help to make an attractive and creative presentation slides 
online. Prezi provides more free space to express creations and ideas in making presentation slides. One of the advantages of Prezi is using the Zooming User Interface (ZUI), which allows Prezi users to zoom in and out the display presentation media. Wisnu (2011) By using ZUI (Zooming User Interface) technology, users can zoom in and zoom out the frame in a presentation. Prezi can zoom in or zoom out of a slide quickly with a beautiful display.

Prezi Next is a completely new presentation platform for Prezi. It is similar to the classic Prezi, however there are major differences in the way the software works, as Prezi Next now runs on HTML5, the classic version works on Adobe Flash software, which is regarded as unsafe with lots of performance issues. Prezi Next can be used to display all presentation images, as well as Power Point.Prezi can also combine various media.

\section{Writing}

There are many experts who define what writing is. Some definitions are given by linguists about writing, according to Boardman \& Frydenberg (2002: 11) define writing as a continuous process of thinking, organizing, rethinking, and recognizing. It means that writing is a process by drawing something based on writer background knowledge and organizes their knowledge into a good sentence. In other hand Williams (2005) stated that writing is one of the four language skills: listening, speaking, reading, and writing. Writing is also one of productive skills which involves communicating message in the form of letters and symbols. In other words, writing skills produce a written product which has 
certain information. From the definitions above, it can be concluded that writing is a productive skill which communicates a message to others by thinking, drafting, and revising the written products. According to Harmer (2004: 31-33) there are some importance of writing. Those are, Writing encourages students to focus on accurate language use because they think as they write, it may provoke well development as they resolve problems which writing puts in their mind. Writing is often used as a means of reinforcing language that has been thought. They use writing skill to make a not about what they have learn while learning process happen. Writing frequently useful as preparation for some other activity.

\section{Recount Text}

Recount text is that tell something in the past. Recount tells a series of event that happened one after the others. Recount text written out to make report an experience of related event (Knapp, 2005). Recount text has social function. The social function of recount text is to tell an event, to entertain, to inform the reader. As Hyland (2003) says the purpose of recount text is to retell event in original sequences by reconstructing past experiences. Other than that, according to Pardiyono (2007) recount is one of the kindof text created with the aim to provide information about activities in the past.

Based on the statement above, we can conclude that recount text which tell about story, event, experience and activity that happen in the past has purpose to inform and to entertain the reader. 


\section{RESEARCH METHODOLOGY AND FINDINGS}

\section{Methodology}

This study applied Research and Development (R\&D) research method. It was adapted from R\&D research method proposed by Borg and Gall (2003). Borg and Gall (2003) stated that the educational R\&D is industry-based development model in which findings of research are used to design new products and a procedure, which is systematically field-tested, evaluated, and refined until they meet specified criteria of effectiveness, quality or similar standard. The subject of this study was eighth grade students of SMP Swasta Panca Abdi Binjai. Based on the writer's preliminary observation, the class consist of 30 students in one class. The writer also obtained that the teaching media used in learning activities not interesting, the school need a variation of teaching media which can improve the students's willingness to learn English. The data has been collected in the form of qualitative and quantitative. The qualitative data would be obtained from the interview of teacher and some students. While quantitative data would be obtained from the questionnaires in form of percentage. The data divided into two forms of data analysis, qualitative data analysis and quantitative data analysis. The data firstly collected, and then this research described the findings. The qualitative data has been analyzed by showing the conclusion of the interview

The research was conducting by adapting Borg and Gall research theory (2003) with some modifications which proposes 6 steps of R\&D Cycle, as follows: 
1. Gathering data and information

2. Need Analysis

3. Media Design

4. Validation to Experts

5. Revising

6. Final product

\section{Findings}

In collecting the data from the source of data, The questionnaire were distributed to 30 students in the eightth grade of SMP Swasta Panca Abdi Binjai. Each individual was given a paper consisted of 12 questions. These needs was divided in two, target and learning needs. The target needs included Necessities, Lacks, and Wants of the Learners, while learning needs included Input, Preffered Topic, and Preffered Media. These two major needs has to be analyzed.

Based on the target data it was found that students' need of attractive learning model is $100 \%$, students' lacks and obstacles in writing English Recount Text through media showed that students tend to be passive in learning English, 25 of them answers that English is a difficult subject. When asked about Ms. Powerpoint is an interesting media or not, 24 answers picked Yes. This indication with the following question about focus during the teaching and learning process with 19 findings that students stayed focus in the class. And students' want in learning English shows that all of them choose answers yes when asked if they like the learning process with slides, animations, illustrations, videos, and 
pictures, Do they agree if Prezi Next used in the class, and Should Prezi Next included in your next English Subject.

Based on learning needs was also about the students's input, and preferred media. The data above showed that media as learning method needed by the students in SMP Swasta Panca Abdi Binjai since writing teaching was considered difficult skill in the class. The teacher also found it difficult to make students understand about the material with only using textual book and video being taught because the lack of the learning media. The teacher also needed a learning media that can make the teaching-learning process less boring and easier to understand. The interest in Recount Text through media would be high since the combination of pictures and text available in Prezi Next. After revising the media, the final product had been completed. The media was already based on the students's needs and appropriate to be used in the teaching learning process which was able to enhance the students's enthusiasm and achievement.

\section{DISCUSSIONS}

This study is aimed to find out the students' need and develop new media for the eightth grade students of SMP Swasta Panca Abdi Binjai. The media developed by the writer is appropriate and related to the students's interest since it is based on their needs analysis. Analyzing the learner's needs based on their interest is one of the way to improve their learning motivation in order to increase their skills in studying English, especially writing skill. The findings show that the learner need motivation to learn and one of them is using the interesting and attractive media. 


\section{CONCLUSION AND SUGGESTIONS}

\section{Conclusion}

The student's recent writing media wasn't effective enough to encourage student's skill. They found it was too difficult to write properly. This also leads to attractive media which introduced to help them motivated and keep interested. This developing media called Prezi Next provided this needs of the users. By following R\&D strategy by Borg and Gall (2003), which were, Gathering Data and Information, Need Analysis, Media Design, Validate by expert, Revision, and the last Final Product. Prezi Next succesfully applied to the users by checking the validation of two experts. The proper scores has been gained. From the material, the first validator scored $75,8 \%$ of excellent, and the score from the second validator was $82,8 \%$, and it was categorized as relevant. And from the media, $52 \%$ from the first validator, and $50 \%$ of the highest score from the second. In means that the media were valid and appropriate to use as learning media for students. This also indicated that the media needed to be develope since it was a new tool to be used by new users.

\section{Suggestions}

There are several suggestions that the writer could offer to reader towards politeness strategy learning, they were.

1. The English teachers can develop the learning quality and they can apply this Prezi Next in their language classroom in order to create interesting and comfortable classroom condition. Then, they can use the product practically as an interactive material in teaching writing. 
2. It also suggested that other writers to add many references to support in developing Writing materials. The questions in questionnaire should be considered to give the students' chance to deliver their wants in learning english specifically in writing skill.

\section{REFERENCES}

Alfiah, T. 2017. Effectiveness of Prezi Multimedia to Improve Japanese Learning Outcomes in Man. Salatiga: Universitas Negeri Semarang.

Arsyad, A. 2011. Media Pembelajaran. Jakarta: PT Raja

Govindo Persada. Borg, W. \& Gall, M. 2003. Education

Research. New York: Allyn and Bacon.

Danasasmita, W. 2009. Metodologi Pembelajaran Bahasa Jepang (Nihongo Kyojuho). Bandung: Rizqi Press.

Depdikbud. 2017. Syllabus of English Lesson for Junior High School/Madrasah Tsanawiyah. Ministry of Education and Culture.

Dirgeyasa, I. 2016. College Academic Writing: A Genre-Based Perspective. Jakarta: Kencana.

Feez, S. \& Joyce, H. 2002. Text-Based Syllabus Design, Sydney: Macquarie University.

Harmer, J. 2004. How to Teach Writing. Essex: Pearson Education

Limited Hyland, K. 2003. Second Language Writing. New York:

Cambridge University 
Press.

Knapp, P. \& Megan, W. 2005. Genre Text, Grammar: Technologies for Teaching and Assessing Writing. Australia: University of New South Wales Press Ltd.

Pardiyono. 2007. Pasti Bisa! Teaching Based Writing. Yogyakarta: CV. Andi Offset.

Pulverness, A. et, al. 2005. Teaching Knowledge Test Course. New York: Cambridge University Press.

Rusman. et, al. 2012. Pembelajaran Berbasis Teknologi Informasi dan Komunikasi: Mengembangkan Profesionalitas Guru. Jakarta: PT Raja Grafindo Persada.

Saputra, I. 2011. CD Tutorial Nonlinear Presentations Series PreziThe Zooming Presentations. Jakarta: Elex Media Komputindo

Vidiasti, N. (2019). Pengembangan Media Pembelajaran Interaktif Prezi Pada Mata Pelajaran Teknologi Informasi Dan Komunikasi (Tik) Kelas Xi Di Sman 1 Pakel. Tulungagung: Jurnal of Education and Informatio: Communication Technology. Vol.3 No. 1

Wardani, F. 2015. Perbandingan Hasil Belajar Siswa dalam Penerapan Problem Based Learning dengan dan Tanpa Dukungan Media Prezi pada Pembelajaran Akutansi Kelas X Di SMK Negeri 2 Nganjuk. Jurnal Pendidikan Akuntansi, 3 (3): 1 - 6.

Wirdayanto, 2017 The Role Of Teaching Media In Learning Language. Surabaya: Widyaiswara Madya BDK. 